\title{
HEALTH RISK ASSESSMENTS OF HEAVY METALS OF PERNA VIRIDIS FROM BANYUURIP WATERS IN UJUNG PANGKAH, GRESIK
}

\author{
Muhammad Fathur Rayyan ${ }^{\mathrm{a}}$, Defri Yona ${ }^{\mathrm{a}, \mathrm{b}} *$, Syarifah Hikmah Julinda Sari ${ }^{\mathrm{a}, \mathrm{b}}$ \\ ${ }^{a}$ Marine Science Department, Faculty of Fisheries and Marine Science, \\ University of Brawijaya, Malang, Indonesia \\ ${ }^{\mathrm{b}}$ Marine Resource Explore Management (MEXMA), Faculty of Fisheries and Marine Science, \\ University of Brawijaya, Jl. Veteran Malang, Indonesia \\ *Koresponden penulis : defri.yona@ub.ac.id
}

\begin{abstract}
Abstrak
Banyuurip merupakan salah satu desa di Kecamatan Ujung Pangkah, Gresik dengan aktivitas budidaya Perna viridis yang tinggi. Kerang Hijau banyak diproduksi dari daerah ini. Meskipun demikian, Perairan Banyuurip juga berpotensi terhadap polusi logam berat. Penelitian ini bertujuan untuk mengetahui konsentrasi logam $\mathrm{Fe}$ dan $\mathrm{Zn}$ pada sedimen dan kerang. Berdasarkan konsentrasi logam, dilakukan analisis Bio Concentration Factor (BCF) dan penilaian terhadap resiko kesehatan manusia. Sampel kerang hijau sejumlah 45 ekor diambil dari 3 titik sampling di Perairan Banyuurip. Untuk memperoleh sampel yang representative, diambil sebanyak 15 ekor kerang hijau dengan ukuran yang sama disertai dengan sampel sedimen dasar laut dari masing-masing titik. Logam berat dianalisis dengan menggunakan AAS (AAnalyst700) untuk mengetahui konsentrasi pada jaringan kerang dan sedimen. Hasilnya berupa konsentrasi Fe yang ditemukan tidak jauh berbeda dengan konsentrasi Zn pada $P$. viridis dengan kisaran $\mathrm{Fe}=3,10-5,25 \mathrm{mg} / \mathrm{kg}$ dan $\mathrm{Zn}=3,91-4,67 \mathrm{mg} / \mathrm{kg}$. BCF (o-s) Fe pada $P$. viridis nilainya lebih rendah dibandingkan dengan $\mathrm{BCF}$ (o-s) Zn, karena Fe pada kerang konsentrasinya lebih kecil daripada konsentrasinya pada sedimen. Berdasarkan perhitungan nilai Target Hazard Quotients, hasilnya (THQ < 1) yang berarti kedua logam berat (Fe dan $\mathrm{Zn}$ ) tidak menimbulkan dampak terhadap kesehatan manusia. Namun, berdasarkan Estimated Daily Intakes (EDI) nilainya berada di atas Provisional Tolerable Daily Intakes (PTDI), sehingga dapat disimpulkan bahwa konsumsi harian kerang hijau secara berlebihan dapat menimbulkan efek negatif bagi kesehatan (EDI > PTDI).
\end{abstract}

Kata kunci: Logam berat, Perna viridis, Bio Concentration Factor, Human Health Risk Assessments, Gresik

\begin{abstract}
Banyuurip is one of villages in Ujung Pangkah District, Gresik with high aquaculture activities of Perna viridis. Green mussels are highly produced in that area, however Banyuurip waters also has potential risk of heavy metals pollution. Therefore, this research was conducted to understand the concentrations of Fe and $\mathrm{Zn}$ in the sediments and in the Green Mussels. The heavy metals concentration will be used to analyze Bio Concentration Factor (BCF) and Human Health Risk Assessments (HHRA). A total about 45 P. viridis populations were collected from 3 sites in Banyuurip waters. In order to obtain a representative sample at each site, 15 populations of Green Mussels with similar shell lengths and bottom sediment were collected. Mussel's tissue and bottom sediment were analyzed using AAS (AAnalyst700) to determine the concentrations of Fe and $\mathrm{Zn}$. The concentrations of Fe were found almost similar with the concentrations of $\mathrm{Zn}$ in $\mathrm{P}$. viridis within the range of $\mathrm{Fe}=3.10-5.25 \mathrm{mg}^{\mathrm{kg}} \mathrm{F}^{-1}$ and $\mathrm{Zn}=3.91-4.67$ $m g . \mathrm{kg}^{-1}$. BCF (o-s) of Fe in P. viridis is lower than the BCF (o-s) of Zn, because the concentrations of Fe in the mussels were less than the concentrations in the sediments. According to the Target Hazard Quotients (THQ) values $(T H Q<1)$, both heavy metals are not likely causing negative health effects for human during lifetime. However, Estimated Daily Intakes (EDI) values are above Provisional Tolerable Daily Intakes (PTDI) standard means it can cause negative effects due to daily consumption (EDI > PTDI).
\end{abstract}

Keywords: Heavy Metals, Perna viridis, Bio Concentration Factor, Human Health Risk Assessments, Gresik 


\section{PENDAHULUAN}

Gresik merupakan salah satu kota yang mendapat predikat sebagai kota industri. Oleh sebab itu banyak terdapat pabrik-pabrik besar yang beroperasi di daerah ini. Industri tersebut antara lain ialah industri semen, industri elektronik, dan industri pupuk [1]. Selain itu, juga banyak terdapat berbagai perusahaan lain di bidang minyak bumi dan gas, automotif, dan konstruksi bangunan. Setiap industri maupun perusahaan-perusahaan tersebut tentu memiliki limbah yang dihasilkan dari proses produksinya. Limbah tersebut umumnya akan dibuang ke sungai yang mengalir menuju perairan estuari atau muara sungai.

Perairan estuari Ujung Pangkah merupakan pertemuan antara Laut Jawa dengan muara sungai Bengawan Solo yang terletak di Kabupaten Gresik, Jawa Timur. Perairan ini banyak mengalami degradasi ekosistem yang disebabkan oleh masukan limbah secara terusmenerus. Hal tersebut dikarenakan, estuari menjadi lokasi berkumpulnya zat-zat pencemar yang terbawa oleh aliran sungai. Salah satu dari zat-zat pencemar yang berbahaya ialah logam berat.

Logam berat dapat terlarut dalam air dan mencemari perairan. Selain itu, logam berat dapat pula mengendap dan terakumulasi dalam sedimen tergantung pada kondisi lingkungan perairan tersebut [2]. Logam berat berpindah dari lingkungan ke organisme, dan dari organisme satu ke organisme lain melalui rantai makanan. Proses rantai makanan menyebabkan terjadinya biokonsentrasi dan biomagnifikasi pada tingkat trofik yang lebih tinggi [3]. Dari berbagai jenis logam berat, ada yang bersifat esensial maupun non-esensial. Logam yang bersifat esensial diantaranya adalah $\mathrm{Fe}$ dan $\mathrm{Zn}$.

Besi (Fe) dan Seng ( $\mathrm{Zn})$ merupakan unsur-unsur logam dengan konsentrasi yang relatif kecil dibutuhkan oleh organisme untuk menjalankan fungsi sel-sel dan organ makhluk hidup. Meskipun kandungan $\mathrm{Fe}$ dan $\mathrm{Zn}$ secara alami telah tersedia di alam, kedua logam tersebut menarik perhatian untuk diketahui kadarnya dalam tubuh organisme tertentu. Kerang merupakan contoh organisme perairan yang dapat dijadikan sebagai bioindikator untuk mengukur kandungan logam berat [4]. Pada penelitian ini, contoh kerang diambil dari perairan di sekitar Desa Banyuurip, Kecamatan Ujung Pangkah, Gresik.

Desa Banyuurip merupakan daerah penghasil kerang untuk wilayah Gresik dan sekitarnya. Kerang memiliki kemampuan untuk mengakumulasi logam dari lingkungan [5]. Kerang hijau (Perna viridis) merupakan jenis kerang yang banyak dibudidayakan oleh masyarakat desa Banyuurip. Kerang hijau dapat muncul dan tumbuh secara alami di perairan laut. Masyarakat sekitar menggunakan bambu yang kemudian ditancapkan ke dasar laut sebagai media untuk ditumbuhi oleh kerang hijau.

Berdasarkan informasi yang diperoleh, tidak hanya kerang jenis ini yang dapat ditemukan di perairan Ujung Pangkah. Namun, kerang hijau yang paling banyak dihasilkan dari proses budidaya oleh masyarakat. Dengan semakin tingginya permintaan pasar, maka akan semakin besar pula produksi kerang yang diupayakan oleh nelayan untuk memenuhinya. Hal tersebut menjadi perhatian, karena biota khususnya kerang yang telah terkontaminasi bahan pencemar (seperti logam berat), apabila dikonsumsi oleh manusia dapat menyebabkan akumulasi di dalam tubuhnya.

Penelitian ini bertujuan untuk mengetahui konsentrasi logam berat $\mathrm{Fe}$ dan $\mathrm{Zn}$ dalam sedimen dan kerang hijau (Perna viridis) yang terdapat di perairan Desa Banyuurip, Ujung Pangkah, Gresik. Selanjutnya, dilakukan analisis mengenai Bio Concentration Factor (BCF) logam berat $\mathrm{Fe}$ dan $\mathrm{Zn}$ dalam kerang hijau (Perna viridis), serta analisis penilaian terhadap resiko kesehatan manusia terhadap konsumsi pada kerang yang telah terakumulasi oleh logam berat.

\section{MATERI DAN METODE}

Sampel $P$. viridis dan sedimen diambil dari 3 titik sampling di sekitar area budidaya kerang hijau di Perairan Banyuurip, Ujung Pangkah, Gresik (Gambar 1). Pengambilan sampel dilakukan pada tanggal 13 - 15 Maret 2018, dengan metode purposive sampling, yaitu secara sengaja melakukan pengukuran parameter kualitas perairan dan mengambil sampel kerang pada titik lokasi yang telah ditentukan. Penentuan titik pengambilan sampel tersebut berdasarkan informasi dari nelayan setempat mengenai lokasi keberadaan kerang hijau. Pengukuran kualitas perairan dilakukan 
menggunakan alat AAQ Rinko 1183, dengan parameter yang diukur meliputi suhu, $\mathrm{pH}, \mathrm{DO}$, salinitas, dan turbiditas.

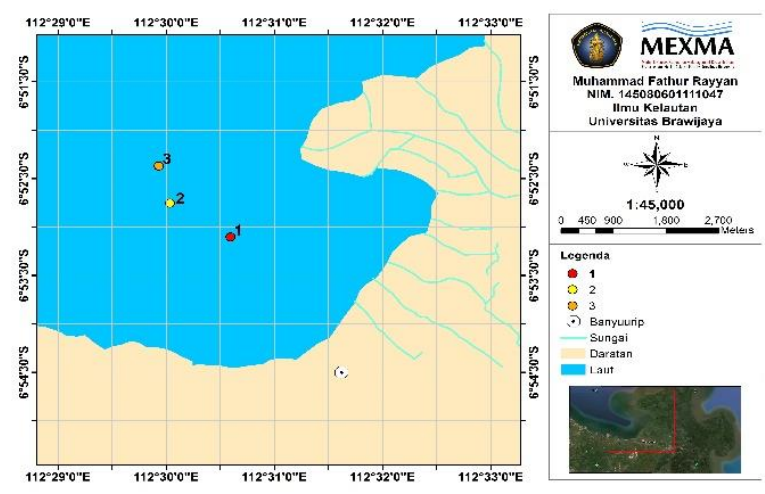

Gambar 1. Peta lokasi pengambilan sampel

Sampel kerang hijau diambil secara acak sebanyak 15 - 20 ekor pada setiap titik, lalu dipilah dengan ukuran cangkang $\pm 5 \mathrm{~cm}$, dan sedimen diambil dengan menggunakan alat Ekman Grab.

Preservasi sampel kerang dan sedimen dilakukan di Laboratorium Hidrologi Divisi Biota Perairan Fakultas Perikanan dan Ilmu Kelautan Universitas Brawijaya. Metode yang digunakan dalam preservasi sampel mengacu pada Standar Nasional Indonesia (SNI) 2354:2011 tentang Penentuan Kadar Logam Berat pada Produk Perikanan.

Sampel kerang dibedah terlebih dahulu dengan menggunakan pisau untuk mengeluarkan seluruh jaringan kerang. Tahap preservasi berikutnya dilakukan prosedur yang sama untuk sampel sedimen. Sampel diletakkan pada nampan yang telah dilapisi alumunium foil dan dikeringkan dalam oven dengan suhu $105^{\circ} \mathrm{C}$ selama 24 jam untuk menghilangkan kadar air pada kerang maupun sedimen. Sampel yang telah mengering digerus hingga halus menggunakan mortal dan alu. Sampel yang telah halus ditimbang sebanyak 1 gram, kemudian dimasukkan ke dalam erlenmeyer. Setelah itu, ditetesi $\mathrm{HNO}_{3}$ pekat sebanyak $5 \mathrm{ml}$ untuk mendestruksi sampel. Dilapisi ujung erlenmeyer dengan alumunium foil agar larutan sampel tidak menguap, lalu didiamkan selama 24 jam. Destruksi dilanjutkan dengan memanaskan sampel di atas hot plate pada suhu $60^{\circ} \mathrm{C}$ selama 2 jam. Setelah dipanaskan, didiamkan kembali pada suhu ruang selama 2 jam. Ditambahkan 15 ml larutan aquades kemudian dilakukan proses penyaringan. Hal itu bertujuan untuk mendapatkan larutan murni tanpa partikel tersuspensi. Larutan hasil penyaringan dimasukkan ke dalam botol vial dan siap untuk dilakukan uji AAS.

Kandungan logam berat $\mathrm{Fe}$ dan $\mathrm{Zn}$ pada kerang hijau dan sedimen dianalisis menggunakan AAS (AAnalyst700) di Laboratorium Kimia Terpadu FMIPA Universitas Negeri Surabaya.

\section{Bio Concentration Factor}

Berdasarkan konsentrasi logam berat yang telah diketahui, selanjutnya dilakukan analisis Bio Concentration Factor (BCF). Menurut El Nemr et al., Bio Concentration Factor (BCF os) merupakan estimasi bioakumulasi logam berat yang terdapat pada jaringan lunak suatu biota [5]. Hal tersebut, berkaitan dengan kemampuan biota (kerang) dalam menyerap logam berat pada media tempat tinggalnya (sedimen). BCF o-s dapat dihitung dengan menggunakan persamaan berikut:

$$
\mathrm{BCF}=\frac{\mathrm{Co}}{\mathrm{Cs}}
$$

Dimana, Co merupakan rata-rata konsentrasi dari masing-masing logam berat $(\mathrm{mg} / \mathrm{kg})$ dalam satu organisme, sedangkan Cs merupakan rata-rata konsentrasi logam berat $(\mathrm{mg} / \mathrm{kg})$ dalam sedimen.

Analisis penilaian terhadap resiko kesehatan manusia terdiri dari Target Hazard Quotients (THQ), Hazard Index (HI), dan Estimated Daily Intakes (EDI).

\section{Target Hazard Quotients}

Target Hazard Quotients (THQ) bertujuan untuk menilai dampak merugikan terhadap kesehatan yang disebabkan oleh suatu logam. Nilai tersebut ditujukan bagi konsumen kerang tingkat menengah (ALM) dan konsumen kerang tingkat tinggi (HLM). ALM merupakan kategori bagi konsumen yang tingkat konsumsi kerangnya dinilai sebesar $0,125 \mathrm{~kg} /$ minggu (atau 17,86 g/hari), sedangkan HLM merupakan konsumen dengan tingkat konsumsi dua kali lipat dibandingkan ALM, yaitu sebesar 0,250 $\mathrm{kg} /$ minggi (atau 35,7 g/hari).

Frekuensi paparan (EF) merupakan jumlah paparan yang diterima dalam kurun durasi paparan, yaitu selama 365 hari/tahun. Durasi paparan (ED) ialah kurun waktu dari suatu organisme hidup yang terpapar oleh agen biologis, fisik, maupun kimia. Nilai ED sebesar 
70 tahun, mendeskripsikan rata-rata usia manusia seumur hidupnya. Referensi dosis konsumsi (ORD) dalam penelitian digunakan untuk mengevaluasi Estimated Daily Intakes (EDI) suatu logam berat yang terkandung pada kerang. Nilai ORD suatu logam berat merupakan konstanta yang telah ditetapkan oleh United States Environmental Protection Agency (USEPA).

Nilai THQ dikenal sebagai parameter yang berguna dalam penilaian resiko kesehatan manusia terhadap logam yang terkandung dalam kerang [6]. Rumus untuk menentukan nilai THQ adalah sebagai berikut:

$$
\mathrm{THQ}=\frac{(\mathrm{EF} \times \mathrm{ED} \times \mathrm{CR} \times \mathrm{Mc})}{(\mathrm{ORD} \times \mathrm{ABW} \times \mathrm{AET})} \times 10^{-3}
$$

Dimana,

EF : Frekuensi paparan (365 hari/tahun)

ED: Durasi paparan (70 tahun)

CR: Tingkat konsumsi (ALM : 17,86 g/hari, HLM : 35,7 g/hari)

Mc: Rata-rata konsentrasi logam pada kerang (mg/kg ww)

ORD: Referensi dosis konsumsi (mg/kg/hari)

Fe: $7,0 \times 10^{-1}$; dan Zn: $3,0 \times 10^{-1}$ (USEPA)

ABW: Rata-rata berat badan $(60 \mathrm{~kg}$ untuk dewasa)

AET: Rata-rata waktu paparan untuk nonkarsinogenik (365 hari/tahun $\mathrm{x}$ ED)

$10^{-3}$ : Unit faktor konversi

Apabila nilai THQ > 1, maka menunjukkan bahwa tingkat paparan lebih tinggi daripada ORD, yang mengasumsikan bahwa paparan harian pada tingkat ini cenderung menyebabkan efek kesehatan negatif selama masa hidup populasi manusia tersebut.

\section{Hazard Index}

Hazard Index (HI) digunakan untuk menilai kemungkinan dampak kesehatan yang ditimbulkan bagi manusia akibat kombinasi dari seluruh logam berat yang dipelajari. Menurut [6], Tabel 1. Rata-rata hasil pengukuran parameter kualitas air
HI dihitung melalui penjumlahan seluruh nilai THQ dari tiap logam berat yang telah ditentukan, dengan rumus sebagai berikut:

$$
\mathrm{HI}=\sum_{\mathrm{i}=1}^{\mathrm{n}} \mathrm{THQ}_{\mathrm{i}}
$$

Dimana, $\mathrm{THQ}_{\mathrm{i}}$ merupakan Target Hazard Quotients dari suatu logam berat, sedangkan nilai $\mathrm{n}$ adalah jumlah logam berat yang dipelajari (dua jenis yaitu $\mathrm{Fe}$ dan $\mathrm{Zn}$ ).

\section{Estimated Daily Intakes}

EDI bagi konsumen ALM dan HLM bertujuan untuk menilai peringatan dampak merugikan bagi kesehatan yang diakibatkan oleh suatu jenis logam berat. Menurut USEPA, penilaian potensi paparan suatu logam berat yang berbahaya melalui konsumsi kerang oleh populasi manusia, dapat dikalkulasikan dengan formula berikut [7]:

$$
\mathrm{EDI}=\frac{\text { Mc } \mathrm{x} \text { CR }}{\text { body weight }}
$$

Dimana, Mc adalah konsentrasi logam pada kerang $(\mathrm{mg} / \mathrm{kg}), \mathrm{CR}$ adalah tingkat konsumsi dari konsumen kategori ALM dan HLM, sedangkan body weight adalah berat badan ratarata orang dewasa sebesar $60 \mathrm{~kg}$.

\section{HASIL DAN PEMBAHASAN}

\section{Parameter Kualitas Perairan}

Pada Tabel 1 disajikan rata-rata $(n=5)$ hasil pengukuran parameter kualitas perairan pada sembilan titik pengambilan sampel:

$P$. viridis ditemukan pada perairan dengan rentang suhu sebesar $28,5-28,8{ }^{\circ} \mathrm{C}$. Suhu tersebut masih tergolong normal bagi perairan. Pernyataan tersebut sesuai dengan yang dikemukakan oleh Kusumawati dan Suprapto, bahwa suhu optimum bagi pertumbuhan kerang berkisar antara $26-32{ }^{\circ} \mathrm{C}$ [8]. Nilai $\mathrm{pH}$ juga masih dapat dikatakan normal, meskipun terdapat dua titik yang nilainya telah melebihi

\begin{tabular}{cccccc}
\hline & \multicolumn{5}{c}{ Hasil Pengukuran Parameter \pm Std. Deviasi } \\
\cline { 2 - 6 } Titik & $\begin{array}{c}\text { Suhu } \\
\left({ }^{\mathbf{0}} \mathbf{C}\right)\end{array}$ & $\mathbf{p H}$ & $\begin{array}{c}\text { DO } \\
(\mathbf{m g} / \mathbf{L})\end{array}$ & $\begin{array}{c}\text { Salinitas } \\
(\%)\end{array}$ & $\begin{array}{c}\text { Kekeruhan } \\
(\mathbf{N T U})\end{array}$ \\
\hline $\mathbf{1}$ & 28,8 & 8,4 & 2,5 & 32 & 93,3 \\
$\mathbf{2}$ & 28,5 & 8,6 & 4,1 & 32,3 & 51,5 \\
$\mathbf{3}$ & 28,5 & 8,8 & 5,2 & 32,3 & 291,2 \\
\hline
\end{tabular}


baku mutu menurut KepMen LH No. 51 Tahun 2004 tentang baku mutu air laut untuk biota, dimana $\mathrm{pH}$ perairan yang baik berkisar antara 7 $-8,5$.

Berdasarkan hasil pengukuran, titik satu memiliki kadar DO yang cukup rendah, yaitu 2,5 mg/L. Hal tersebut dapat disebabkan karena pada titik satu terdapat beberapa jenis ikan yang dipelihara dalam keramba jaring di bawah rumpon bambu. Tujuannya sebagai destinasi bagi wisatawan yang hendak memancing di sekitar area budidaya kerang hijau. Dengan semakin banyaknya organisme yang hidup pada suatu perairan, maka semakin meningkat pula kebutuhan oksigen yang diperlukan oleh organisme. Hal itu berdampak terhadap penurunan kadar DO pada perairan tersebut [9].

Faktor lain yang mungkin berpengaruh dapat berupa banyaknya kandungan limbah organik. Apabila perairan banyak mengandung limbah organik, maka bakteri membutuhkan lebih banyak oksigen untuk menguraikan zat organik sehingga oksigen yang ada di perairan akan berkurang [10]. Dengan demikian, dapat disimpulkan bahwa kadar DO pada titik satu berada di bawah baku mutu KepMen LH No. 51 Tahun 2004 tentang air laut untuk biota karena nilainya kurang dari $5 \mathrm{mg} / \mathrm{L}$. Kerang $P$. viridis yang ditemukan hidup pada salinitas sekitar 32 ppt. Nilai tersebut sedikit berada di atas batas normal salinitas yang optimal bagi pertumbuhan kerang, yaitu kisaran $28-31 \%$ [8].

Paramater kualitas perairan yang paling bervariasi nilainya adalah kekeruhan (turbiditas). Kondisi perairan Banyuurip sangat keruh dengan visibilitas dalam air yang sangat rendah $(<30 \mathrm{~cm})$. Hal ini diperkuat dengan hasil pengukuran, rata-rata nilai kekeruhan di lokasi penelitian berkisar antara 99,3 - 291,2 NTU (Nephelometric Turbidity Unit). Rentang nilai tersebut berada sangat jauh di atas baku mutu kekeruhan berdasarkan KepMen LH No. 51 Tahun 2004 untuk biota laut, yaitu sebesar $\leq 5$ NTU.

Keruhnya perairan tersebut dapat disebabkan oleh lokasinya yang berada dekat dengan muara sungai Bengawan Solo, dimana aliran sungai membawa partikel-partikel tersuspensi dan sedimen lumpur kemudian mengendap di dasar perairan. Kekeruhan memiliki korelasi positif terhadap padatan tersuspensi, yaitu semakin tinggi nilai kekeruhan maka semakin tinggi pula nilai padatan tersuspensinya [11].

\section{Konsentrasi Logam Berat pada Sedimen dan Kerang}

Kerang merupakan organisme yang hidup menetap, bersifat filter feeder dan mampu berkembang biak pada tekanan ekologis yang tinggi. Seiring dengan pertumbuhan, kerang mampu mengakumulasi logam berat dalam tubuhnya jika hidup pada perairan yang terkontaminasi oleh logam berat [12]. Logam berat $\mathrm{Fe}$ dan $\mathrm{Zn}$ yang ada pada sedimen dapat masuk kemudian terakumulasi dalam tubuh kerang. Oleh sebab itu, kadar logam berat dalam kerang perlu diukur untuk mengetahui perbandingan konsentrasinya dengan sedimen.

Konsentrasi logam berat yang terkandung dalam sedimen dan kerang hijau ditampilkan masing-masing pada Tabel 2 dan Tabel 3.

Tabel 2. Rata-Rata Konsentrasi Logam Berat pada Sedimen

\begin{tabular}{ccc}
\hline \multirow{2}{*}{ Titik Lokasi } & Fe & Zn \\
\cline { 2 - 3 } & $(\mathbf{m g} / \mathbf{k g})$ & $(\mathbf{m g} / \mathbf{k g})$ \\
\hline 1 & 76,79 & 1,65 \\
2 & 76,09 & 1,68 \\
3 & 74,41 & 1,615 \\
\hline Rata-rata & $\mathbf{7 5 , 7 6}$ & $\mathbf{1 , 6 5}$ \\
\hline
\end{tabular}

Berdasarkan hasil yang ditampilkan pada Tabel 2, konsentrasi $\mathrm{Fe}$ pada sedimen di Perairan Banyuurip berkisar antara 74,41 $76,79 \mathrm{mg} / \mathrm{kg}$, sedangkan $\mathrm{Zn}$ berkisar antara $1,615-1,68 \mathrm{mg} / \mathrm{kg}$. Kandungan Fe yang lebih tinggi pada sedimen dapat bersumber dari masukan limbah logam berat yang berasal dari aliran sungai, kemudian mengalami proses pengendapan. Karena Fe termasuk logam yang multiguna dan banyak dimanfaatkan untuk bahan baku industri pengolahan logam. Hal ini menyebabkan semakin tinggi pula potensi sumber pencemar logam $\mathrm{Fe}$ pada perairan, seperti korosi pipa-pipa, kapal dan anjungan lepas pantai, limbah pertanian meliputi pupuk dan pestisida, industri baja, keramik, dan baterai.

Selain itu, Fe juga diperlukan bagi makhluk hidup, contohnya sebagai mikronutrien untuk pertumbuhan fitoplankton maupun organisme perairan lainnya. Di samping pemanfaatannya yang luas, sehingga berpotensi tinggi untuk menghasilkan limbah yang dapat mencemari lingkungan, hal mendasar yang 
berpengaruh terhadap tingginya kandungan $\mathrm{Fe}$ dalam sedimen ialah disebabkan oleh keberadaannya secara alami yang telah tersedia dalam jumlah besar di alam [13].

Berbeda halnya dengan unsur $\mathrm{Zn}$ yang memiliki sifat tidak stabil. Karena dalam sedimen, $\mathrm{Zn}$ mudah bereaksi dengan $\mathrm{Fe}$ hidroksida dan $\mathrm{Mn}$ dioksida $\left(\mathrm{MnO}_{2}\right)$. Kecenderungan ion $\mathrm{Zn}$ lebih kuat diserap senyawa $\mathrm{Mn}$ oksida dibandingkan dengan $\mathrm{Fe}$ oksida. Diperkuat oleh Jones (1987) yang menyebutkan bahwa unsur $\mathrm{Zn}$ dapat dengan mudah berikatan dengan senyawa Fe hidroksida [14]. Hal tersebut menyebabkan kandungan $\mathrm{Zn}$ sedikit dalam sedimen.

Tabel 3. Konsentrasi Logam Berat pada P. viridis

\begin{tabular}{ccc}
\hline \multirow{2}{*}{ Titik Lokasi } & $\mathbf{F e}$ & $\mathbf{Z n}$ \\
\cline { 2 - 3 } & $(\mathbf{m g} / \mathbf{k g})$ & $(\mathbf{m g} / \mathbf{k g})$ \\
\hline 1 & 5,25 & 4,67 \\
2 & 4,69 & 3,91 \\
3 & 3,10 & 4,26 \\
\hline Rata-rata & 4,35 & 4,28 \\
\hline
\end{tabular}

Berdasarkan Tabel 3, diketahui bahwa konsentrasi $\mathrm{Fe}$ yang terakumulasi oleh $P$. viridis berada pada kisaran 3,10 hingga $5,25 \mathrm{mg} / \mathrm{kg}$, sedangkan konsentrasi $\mathrm{Zn}$ dalam kerang hijau berkisar antara 3,91 - 4,67 mg/kg. Perbedaan karakteristik masing-masing logam bagi organisme perairan lebih memberikan pengaruh yang nyata terhadap tingkat akumulasi yang terjadi. Diawali dengan penjelasan mengenai unsur $\mathrm{Fe}$, besi hadir di perairan laut dalam bentuk senyawa oksida-hidroksida contohnya Besi (II) hidroksida $\left(\mathrm{Fe}(\mathrm{OH})_{2}\right)$, Besi (III) hidroksida $\left(\mathrm{Fe}(\mathrm{OH})_{3}\right)$, unsur bebas maupun senyawa kompleks organik [13]. Senyawasenyawa oksihidroksida besi tersebut mengalami pengendapan secara cepat pada salinitas tinggi (di atas $10 \mathrm{ppt}$ ). Pada perairan laut yang rendah oksigen, besi dimobilisasi dari sedimen dan berdifusi ke kolom perairan. Sebagian besar besi yang hadir di kolom perairan ialah dalam bentuk partikulat, dimana partikulat tersebut yang diserap oleh kerang sehingga terakumulasi dalam tubuhnya. Unsur besi dibutuhkan sebagai mikronutrien bagi kerang untuk proses metabolisme [6].

Faktor lain yang turut mempengaruhi distribusi $\mathrm{Zn}$ di perairan ialah pemanfaatannya oleh organisme akuatik. Zn memegang peranan penting bagi metabolisme mikro-organisme di perairan, seperti coccolithophorids, cyanobacteria dan diatoms [15]. Apabila seng telah banyak dimanfaatkan oleh organisme di kolam perairan, maka unsur yang mengendap jumlahnya akan sedikit. Meskipun jumlah unsur $\mathrm{Zn}$ sedikit yang mengendap dalam sedimen, namun kerang hijau dapat pula menyerap unsur logam yang ada di perairan. Proses penyerapan yang terjadi oleh organisme kerang secara terusmenerus dalam kurun waktu tertentu mengakibatkan akumulasi logam berat pada jaringannya, sehingga nilai konsentrasi yang diperoleh lebih tinggi daripada yang terkandung dalam sedimen.

\section{Bio Concentration Factor}

Hasil perhitungan $\mathrm{BCF}$ o-s ditampilkan pada Tabel 4:

Tabel 4. Nilai faktor biokonsentrasi (BCF o-s) logam Fe dan $\mathrm{Zn}$ dalam $P$. viridis

\begin{tabular}{ccc}
\hline \multirow{2}{*}{ Jenis Kerang } & $\mathbf{F e}$ & $\mathbf{Z n}$ \\
\cline { 2 - 3 } & $(\mathbf{m g} / \mathbf{k g})$ & $\mathbf{( m g / k g )}$ \\
\hline P. viridis & 0,07 & 2,83 \\
P. viridis & 0,06 & 2,33 \\
P. viridis & 0,04 & 2,64 \\
\hline Rata-rata & $\mathbf{0 , 0 6}$ & $\mathbf{2 , 6 0}$ \\
\hline
\end{tabular}

Berdasarkan Tabel 4, tingginya nilai akumulasi logam berat $\mathrm{Zn}$ dibandingkan $\mathrm{Fe}$ disebabkan oleh konsentrasi $\mathrm{Zn}$ yang terukur dalam kerang lebih tinggi dibandingkan konsentrasi logam beratnya dalam sedimen. Karena biokonsentrasi merupakan rasio perbandingan, apabila konsentrasi logam dalam kerang lebih tinggi dibandingkan dengan konsentrasinya pada lingkungan (sedimen), maka nilai biokonsentrasinya juga akan tinggi. Berlaku pula sebaliknya, dengan konsentrasi logam berat Fe dalam kerang yang nilainya jauh lebih rendah dibandingkan konsentrasi logam berat dalam sedimen, maka nilai biokonsentrasinya juga ikut rendah. Oleh sebab itu, dapat disimpulkan bahwa biokonsentrasi logam berat $\mathrm{Zn}$ pada kerang lebih tinggi dibandingkan logam berat $\mathrm{Fe}(\mathrm{Zn}>\mathrm{Fe})$. 


\section{Target Hazard Quotients}

Nilai THQ yang ditampilkan merupakan analisis dari resiko paparan logam berat $\mathrm{Fe}$ dan $\mathrm{Zn}$ dari sampel kerang $P$. viridis di perairan Banyuurip, Ujung Pangkah, Gresik. Hasil perhitungan THQ dan HI disajikan pada Tabel 5:

Tabel 5. Nilai THQ dan HI untuk konsumen kategori ALM dan HLM

\begin{tabular}{|c|c|c|c|c|}
\hline \multirow{2}{*}{$\begin{array}{l}\text { Jenis } \\
\text { Kerang }\end{array}$} & & \multicolumn{2}{|c|}{ THQ } & \multirow{2}{*}{ HI } \\
\hline & & $\mathrm{Fe}$ & Zn & \\
\hline \multirow{2}{*}{ P. viridis } & ALM & 0,0018 & 0,0042 & 0,0061 \\
\hline & HLM & 0,0037 & 0,0085 & 0,0122 \\
\hline
\end{tabular}

Berdasarkan hasil perhitungan pada Tabel 5, disimpulkan bahwa nilai THQ logam berat Fe dan Zn pada masing-masing kerang berada jauh di bawah angka 1. THQ logam $\mathrm{Fe}$ untuk kategori konsumen ALM adalah sebesar 0,0018, sedangkan nilai THQ dari logam Zn untuk konsumen ALM pada kerang hijau sebesar 0,0042. Nilai THQ dalam kerang hijau untuk kategori ALM maupun HLM tidak ada yang melebihi angka 1.

Begitu pula dengan nilai HI, yang merupakan kalkulasi nilai THQ dari kedua logam (Fe dan $\mathrm{Zn}$ ) juga menunjukkan nilai kurang dari 1 atau $\left(\sum \mathrm{THQ}=\mathrm{HI}\right)<1$. Maka dapat disimpulkan bahwa, kadar Fe dan Zn yang terkandung dalam kerang hijau di perairan Banyuurip tidak berpotensi terhadap resiko kesehatan bagi konsumennya.

\section{Estimated Daily Intakes}

EDI merupakan estimasi dari asupan logam berat yang masuk ke dalam tubuh manusia melalui konsumsi harian. Penilaian EDI digunakan untuk merepresentasikan asupan harian logam berat. Nilai EDI akan dibandingkan dengan PTDI (Provisional Tolerable Daily Intake) atau toleransi asupan harian logam yang disarankan oleh JECFA (Joint FAO/WHO Expert Committee on Food Additives) tahun 1999. Hasil perhitungan nilai EDI ditampilkan pada Tabel 6:

Tabel 6. Perbandingan nilai EDI dan PTDI

\begin{tabular}{cccc}
\hline \multirow{2}{*}{ Jenis Kerang } & \multicolumn{3}{c}{ EDI } \\
\cline { 2 - 4 } & & $\begin{array}{c}\text { Fe } \\
(\mathrm{mg} / \mathrm{kg} / \mathrm{hari})\end{array}$ & $\begin{array}{c}\mathbf{Z n} \\
(\mathrm{mg} / \mathrm{kg} / \mathrm{hari})\end{array}$ \\
\hline P. viridis & ALM & 1,29 & 1,27
\end{tabular}

\begin{tabular}{rcc} 
HLM & 2,59 & 2,55 \\
\hline Nilai PTDI $^{\text {a) }}(\mathrm{mg} / \mathrm{kg} / \mathrm{hari})$ & 0,7 & 0,3
\end{tabular}

Keterangan:

a) Nilai Provisional Tolerable Daily Intake (PTDI) didasarkan atas ketetapan yang dikeluarkan oleh JECFA (1999), dengan asumsi sama seperti referensi dosis konsumsi (ORD) logam Fe dan $\mathrm{Zn}$ yang ditetapkan oleh USEPA tahun 2015.

Berdasarkan hasil perhitungan nilai EDI pada Tabel 6, diketahui bahwa seluruh logam Fe dan $\mathrm{Zn}$ pada kerang hijau telah melebihi nilai toleransi asupan harian logam berat. Dimana pada kerang hijau nilai EDI untuk $\mathrm{Fe}$ bagi konsumen dengan kategori ALM adalah sebesar $1,29 \mathrm{mg} / \mathrm{kg} / \mathrm{hari}$, sementara kategori HLM sebesar $2,59 \mathrm{mg} / \mathrm{kg} / \mathrm{hari}$. Kedua nilai tersebut telah melebihi PTDI logam Fe yang dikonsumsi oleh manusia sebesar $0,7 \mathrm{mg} / \mathrm{kg} / \mathrm{hari}$. Begitu pula dengan nilai EDI untuk logam $\mathrm{Zn}$, konsumen dengan kategori ALM sebesar 1,27 $\mathrm{mg} / \mathrm{kg} / \mathrm{hari}$ dan kategori HLM sebesar 2,55 $\mathrm{mg} / \mathrm{kg} / \mathrm{hari}$ telah melewati PTDI logam Zn sebesar $0,3 \mathrm{mg} / \mathrm{kg} / \mathrm{hari}$.

Nilai EDI yang melebihi PTDI tersebut dapat disebabkan oleh tingginya tingkat konsumsi (CR) dari individu yang mengonsumsi kerang setiap harinya. Selain itu, karena semua parameter dan konstanta pada persamaan adalah sama, maka nilai EDI juga sangat bergantung pada konsentrasi logam (Mc) dalam masingmasing kerang. Apabila nilai EDI yang dihasilkan melebihi PTDI, maka hal tersebut dapat menjadi peringatan mengenai efek kesehatan merugikan yang mungkin ditimbulkan oleh logam berat yang terkandung dalam kerang konsumsi.

Tingginya estimasi asupan harian kerang ini dapat disebabkan karena Banyuurip merupakan desa penghasil kerang hijau, sehingga tingkat konsumsi masyarakat terhadap kerang cukup tinggi. Pada musim panen (bulan Juli hingga Oktober), nelayan mampu memperoleh hasil tangkapan mencapai 300 $500 \mathrm{~kg}$ kerang per hari. Berdasarkan informasi dari salah seorang nelayan bahwa sebagian besar masyarakat hampir sering mengonsumsi kerang ketika musim panen. Dari hasil perhitungan nilai EDI, maka dapat disimpulkan bahwa kerang yang dikonsumsi secara berlebihan dapat menimbulkan dampak terhadap kesehatan karena mengandung logam berat yang melebihi batas toleransi asupan kerang harian (PTDI). Efek negatif bagi kesehatan akibat mengonsumsi besi dalam jumlah yang tidak ideal bagi tubuh dapat menimbulkan masalah anemia, kepala 
pusing, diare, penurunan nafsu makan, dan gangguan metabolisme [12]. Akibat dari konsumsi Zn pada konsentrasi yang tinggi dapat menyebabkan masalah kesehatan cukup serius, seperti keracunan, sakit perut, kerusakan pankreas, gangguan metabolisme protein dalam tubuh dan arteriosklerosis [6]. Salah satu upaya yang mungkin dilakukan untuk meminimalisir dampak negatif akibat paparan logam berat dalam tubuh ialah dengan mengurangi tingkat konsumsi kerang yang mengandung logam berat.

\section{KESIMPULAN}

Distribusi logam berat Fe dalam sedimen jauh lebih tinggi dibandingkan dengan logam berat $\mathrm{Zn}(\mathrm{Fe}>\mathrm{Zn})$. Konsentrasi Fe yang terakumulasi oleh kerang hijau berada pada kisaran yang sedikit lebih rendah antara 3,10 $5,25 \mathrm{mg} / \mathrm{kg}$, sedangkan konsentrasi $\mathrm{Zn}$ dalam kerang hijau berkisar antara 3,91 - 4,67 mg/kg. Nilai BCF (o - s) logam Zn lebih tinggi dibandingkan dengan logam $\mathrm{Fe}$, karena konsentrasinya pada kerang lebih tinggi dibandingkan konsentrasinya pada sedimen. Penilaian THQ logam Fe dan Zn dari kerang hijau tidak ada yang melebihi nilai 1 . Hal tersebut menandakan bahwa kedua logam tersebut tidak berpotensi menimbulkan resiko kesehatan. Sedangkan penilaian EDI, diperoleh hasil bahwa nilainya telah melebihi PTDI, sehingga dikhawatirkan konsumsi kerang secara berlebihan dapat menimbulkan masalah kesehatan.

\section{UCAPAN TERIMA KASIH}

Terima kasih penulis sampaikan kepada Marine Resources Exploration and Management (MEXMA) Research Group yang telah mendanai sebagian besar dari penelitian ini. Terima kasih juga kepada masyarakat Desa Banyuurip yang turut bekerjasama dalam pengambilan sampel.

\section{REFERENSI}

[1] Basalmah, L. Kandungan Logam Berat $\mathrm{Hg}, \mathrm{Cd}$, dan $\mathrm{Pb}$ dalam Air dan Ikan di Perairan Ujung Pangkah, Jawa Timur. SKRIPSI. Bogor: IPB, Oktober 2006.

[2] Supriyantini, E., dan Endrawati, H. "Kandungan Logam Berat Besi (Fe) Pada Air, Sedimen, Dan Kerang Hijau (Perna viridis) Di Perairan Tanjung Emas Semarang.” J. Kelaut. Trop. 18, Juni 2015.

[3] Amriarni, A., Hendrarto, B., dan Hadiyarto, A. "Bioakumulasi logam berat timbal $(\mathrm{Pb})$ dan seng $(\mathrm{Zn})$ pada kerang darah (Anadara granosa L.) dan kerang bakau (Polymesoda bengalensis L.) di perairan Teluk Kendari." J. Ilmu Lingkung. 9, hal. 45-50, 2011.

[4] Supriatno, S., dan Lelifajri, L. "Analisis logam berat $\mathrm{Pb}$ dan $\mathrm{Cd}$ dalam sampel ikan dan kerang secara spektrofotometri serapan atom." J. Rekayasa Kim. Lingkungan vol. 7, no. 1, hal. 5-8, 2009.

[5] El Nemr, A., El-Said, G.F., Ragab, S., Khaled, A., dan El-Sikaily, A. "The distribution, contamination and risk assessment of heavy metals in sediment and shellfish from the Red Sea coast, Egypt." Chemosphere 165, hal. 369-380, 2016.

[6] Yap, C.K., Cheng, W.H., Karami, A., dan Ismail, A. "Health risk assessments of heavy metal exposure via consumption of marine mussels collected from anthropogenic sites." Science of the Total Environment 553, hal. 285-296, 2016.

[7] USEPA. US Environmental Protection Agency. "Guidance manual for assessing human health risks from chemically contaminated, fish and shellfish." USEPA, Washington DC. 2015.

[8] Kusumawati, L.A., dan Suprapto, D. "Filtration Rate Kerang Darah Dan Kerang Hijau Dalam Memfiltrasi Bahan Organik Tersuspensi Limbah Tambak Udang Intensif.” Manag. Aquat. Resour. J. 4, 131-137, 2015.

[9] Salmin. "Oksigen Terlarut (DO) dan Kebutuhan Oksigen Biologi (BOD) sebagai Salah Satu Indikator untuk Menentukan Kualitas Perairan." Oseana, Volume XXX (3) : 21 - 26, 2005.

[10] Simanjuntak, M. "Oksigen Terlarut dan Apparent Oxygen Utilization di Perairan Teluk Klabat, Pulau Bangka." Ilmu Kelautan, vol. 12, no. 2 : 59 - 66, 2007.

[11] Pujiastuti, P., dan Ismail, B. "Kualitas dan Beban Pencemaran Perairan Waduk Gajah Mungkur.” 17, 2013. 
[12] Triantoro, D. D., Suprapto, D., dan Rudiyanti, S. "Kadar Logam Berat Besi $(\mathrm{Fe})$, Seng ( $\mathrm{Zn})$ Pada Sedimen Dan Jaringan Lunak Kerang Hijau (Perna viridis) Di Perairan Tambak Lorok Semarang." Journal of Maquares, vol. 6, no. 3, hal. 173-180, 2017, 2017.

[13] Liu, X., dan Millero, F.J. "The solubility of iron in seawater." Mar. Chem. 12, 2002.
[14] Rieuwerts, J.S., Thornton, I., Farago, M.E., and Ashmore, M.R. "Factors influencing metal bioavailability in soils: preliminary investigations for the development of a critical loads approach for metals." Chem. Speciat. Bioavailab. 10, 61-75, Januari 2015.

[15] Thuróczy, C.-E., Boye, M., dan Losno, R. "Dissolution of cobalt and zinc from natural and anthropogenic dusts in seawater." Biogeosciences 7, 1927-1936, Juni 2010. 